\title{
Corporate Entrepreneurship: Nothing Ventured, Nothing Gained?
}

\author{
Susan A. Hill, London Business School \\ Julian Birkinshaw, London Business School \\ Gordon Murray, University of Exeter
}

\begin{abstract}
Recent literature has suggested that adopting elements of the organization of independent venture capital (VC) firms may enhance the performance of corporate venture (CV) units (Chesbrough, 2000; Sahlman, 1990). This assertion has only been subject to minimal empirical research: typically restricted to small-sample qualitative studies or to examining the respective influences of independent VC firms and CV units on the performance of portfolio firms (Gompers \& Lerner, 1998; Maula \& Murray, 2001).

A longitudinal survey of $95 \mathrm{CV}$ units across three continents found mixed empirical support for the suggestion. Of the VC structures and practices investigated, strongest support was found for CV unit engagement with the VC community which was consistently associated with superior corporate venturing performance along both strategic and financial dimensions. VC-like equity-based compensation systems were not found to influence CV performance even where CV units were strongly focused on financial goals. Overall, the adoption of VC practices, partially mediated by venture unit performance, was positively associated with CV unit survival. These results suggest that selective adoption of elements of the VC model may enhance CV unit performance and survival.
\end{abstract}

\section{Introduction}

Corporate venturing is often thought to have a somewhat dubious track record in delivering benefits to parent organizations. In contrast, independent VC firms employing limited partnership structures have become highly prominent in the private equity market and have historically outperformed the S\&P 500 index (Brody \& Ehrlich, 1998; Burgel, 2000). Accordingly, a number of theorists and practitioners have cited VC firms as a possible archetype of "successful venturing" practice to which CV units should aspire (Brody \& Ehrlich, 1998; Chesbrough, 2000; Sahlman, 1990). Little empirical research has examined the soundness of such advice. It is currently difficult to draw robust conclusions about whether elements of a "VC-like" approach can influence corporate venturing performance. The majority of relevant studies have been small sample, case-study research; larger-scale investigations (Gompers \& Lerner, 1998; Maula \& Murray, 2001) have only touched on these issues indirectly.

The approach taken in the present study was, first, to identify archetypal attributes of VC firms which are believed to facilitate superior investment performance, and, second, to examine via a longitudinal survey the relationship between these attributes and measures of CV unit performance and survival. Specifically, our study aimed to address the following research questions:

1. Does the replication of the structures and practices of independent VC firms by CV units enhance corporate venturing performance?

2. Does the replication of the structures and practices of VC firms by CV units increase the likelihood of CV unit survival?

3. If 1 and 2 are shown to be true, which of the identified structures and practices are associated with improved performance and survival?

The study intends to contribute to both practice and theory on corporate venturing. Sorting "hype from reality" regarding the VC industry (Zider, 1998: 132) and its lessons for corporate venturing is currently extremely difficult given the lack of relevant empirical research. Despite recent declines, corporate venturing tends to mirrors the wider macro-economy by following a strongly cyclical path (Chesbrough, 2000; Coveney, Elton, Shah, \& Whitehead, 2002; Sohl, 2002). It is highly probable that we will again experience a new "wave" of venturing necessitating grounded guidance to CV managers. The study contributes to theory by advancing scholarly understanding of organizational and managerial factors that influence CV unit performance and survival -- areas suffering from a lack of systematic, large-scale and/or longitudinal research. In particular, the study addresses the issue of the transferability of the VC governance and value-adding mechanisms to venturing units within large, established firms.

\section{Background to Venture Capital and Corporate Venturing}

CV units are separately managed entities established by large firms with the purpose of investing in and developing new business opportunities (Birkinshaw, 1997; Block \& MacMillan, 1993). Such units may engage in a variety of speculative forms of non-core investment "from making small investments in independent start-ups, to incubating internal business ideas, to spinning out businesses" (Birkinshaw, Batenburg, \& Murray, 2002: 9). The objectives of corporate venture units typically include both strategic and financial dimensions (Chesbrough, 2002; Gompers \& Lerner, 1998; Siegel, Siegel, \& MacMillan, 1988). 
The organizational form of VC firms has received a great deal of attention, primarily in financial economics literature (Sahlman, 1990; Barry, 1994; Gompers \& Lerner, 1999). The dominant organizational form in the organized private equity market is the limited liability partnership (LLP) which is adopted by the great majority of independent VC firms (Fenn, Liang, \& Prowse, 1995). Hellmann (2000) described venture capital as "professionally managed, equity-like financing of young, growth-oriented private companies". In essence, VCs are structured as fixed term partnerships wherein institutional investors are limited partners (LPs) and professional private equity managers are the general partners (GPs). The structure provides substantial autonomy to the GPs over investment decisions (Fenn et. al., 1995). The agency costs that this arrangement may otherwise create is attenuated by strict contracting, the finite lifespan of the fund, and substantial equity-based incentives to the GPs (Fenn et. al., 1995).

The exceptional returns generated by VC firms over the past two decades (Brody \& Ehrlich, 1998; Chesbrough, 200o; Donahoe, Schefter, \& Harding, 2001) have resulted in much interest in distilling "best practice" from these firms and applying it to corporate venturing. Particularly, the dearth of large-scale and/or longitudinal research on determinants of CV unit performance (for earlier studies refer to Fast, 1978; Rind, 1981; Sykes, 1990; Siegel et al., 1988), together with the widespread reputation of corporate venturing as being very challenging and with variable and uncertain benefits, have created fertile ground for the prescription of $\mathrm{VC}$ structures and practices to corporate venturing contexts. Yet, this pragmatic and wide scale prescription has little empirical validation.

\section{Theory and Hypotheses}

The fundamental proposition of VC-model advocates is that the greater the extent to which a corporate venturing unit adopts the structures and practices of the "typical" (LLP) VC firm, the better its performance will be relative to that of other CV units. To make testing this proposition tractable, three key elements of the VC model were identified from VC literature. These were: (1) substantial autonomy over investment decisions (2) the use of high-powered equity-based incentives, and (3) the practices of networking within the VC community and syndicating investment opportunities (Chesbrough, 2000; Donahoe et al., 2001; Fenn et al., 1995; Lerner, 1994; Maula, Autio, \& Murray, 2003; Zider, 1998). The influence of each attribute on CV unit performance will be hypothesized in turn before exploring their combined influence on venture survival.

It is important to recognise at the outset that "blind" replication of the VC model is unlikely to be successful. Corporate venture units are different from VCs by definition in that they are created and controlled by a large firm. As such, they have certain obligations (e.g. investing in areas that are of strategic value to the firm) and constraints on their activities (e.g. rewarding employees on the firm's traditional pay scale) that independent VCs are not subject to. Furthermore, CV units vary significantly on a number of dimensions, most notably their objectives and their internal organizational arrangements. Here we examine CV units in terms of their common features, theorising contingent relationships where generic characteristics represent a major source of internal variation. The resulting hypotheses are shown graphically in Figure 1.

\section{Adoption of VC Model and Unit Performance}

Governance system providing substantial autonomy. As noted, the VC firms' GPs are free to invest the funds under their control without involvement or sanction by the LPs. Consequently, they can respond quickly to investment opportunities (Brody \& Ehrlich, 1998). The application of VC governance systems to CV units would imply that such units are authorised to act independently on day-to-day investment decisions, with high autonomy from both corporate head offices "vertical" autonomy) and from other operating divisions ("horizontal" autonomy).

The issue of how much separation a venture unit should have from its parent company has been well recognized (see Drucker, 1985; Galbraith, 1982; Burgelman, 1984). In extremis, venture capitalists have full autonomy from their investors over and beyond the ten-year investment horizon. Operational autonomy gives CV managers the freedom to decide on the appropriate level of integration for each venture (taking into account issues such as the strategic relatedness of the investment). This structure also provides a mechanism for venture unit managers to manage the oft-quoted conflict of interests between themselves and their corporate parent, e.g. over the time horizon of investments.

\section{Hypothesis 1: The greater the autonomy of a CV unit over investment decisions, the higher the performance of the unit.}

\section{Hypothesis 2: The lesser the involvement of parent company business units in CV unit decision-making, the higher the performance of the unit.}

Carried interest compensation providing high-powered incentives. GPs are rewarded primarily through a carried interest in the equity of the VC fund's portfolio firms. The carry is typically $20 \%$ and may be conditional on a minimum investment performance (the "hurdle"). These incentives may perform a number of important functions for VC firms, including: (1) mitigating principal-agent conflict through incentive alignment, (2) introducing clarity of focus and discipline to VC activities, and (3) attracting highly skilled investment professionals (Brody \& Ehrlich, 1998; Fenn et al., 1995; Gompers \& Lerner, 1998; Sahlman, 1990).

CV units have typically applied standard corporate reward systems to their venture professionals. It is indeed questionable whether VC-like incentive systems can be satisfactorily applied to CV units (Block \& Ornati, 1987; Block \& MacMillan, 1993; Brody \& Ehrlich, 1998; Gompers \& Lerner, 1998). Frequent changes in staffing responsibilities may create difficulties in attributing performance to the $\mathrm{CV}$ team; nor are managers investing or risking any of their own 
money. Individuals who engage in corporate entrepreneurship may weight differently from venture capitalists security of employment versus the possibility of exceptional financial returns (Rumelt, 1987). Additionally, CV managers are typically recruited as career professionals. The CV posting may be one of many offices held in their corporate careers, whilst partners of VC firms usually make permanent commitments to their firms.

Critically, focusing on financial return may also encourage moral hazard by reducing managers' attention paid to the strategic value of investments. Compensation in the form of carried interest may only deliver the benefits of incentive alignment and focus in cases where the goals of the venture unit are predominantly financial. Stated more formally, we expect that the relationship between CV unit adoption of carried interest compensation systems and venture unit performance would be moderated by the unit's emphasis on financial goals:

\section{Hypothesis 3: The greater the focus on financial goals in the CV unit, the greater the impact of equity-based} compensation on the performance of the unit.

Engagement with the VC community. The practice of syndicating investment opportunities between members of the VC community serves a number of functions. It allows VCs to reduce informational asymmetries by pooling judgements from multiple sources of expertise (Gompers \& Lerner, 1999; Lerner, 1994). The expectation of reciprocal syndication allows VC community members to be exposed to more investment opportunities ("deal flow") than would otherwise be the case. Syndication also enables risk sharing (Brody \& Ehrlich, 1998; Wright \& Lockett, 2002).

Frequent communication with VCs may provide CV units with similar benefits to deal syndication, including opportunities to acquire more tacit knowledge regarding VC investment practices and mental models. An association with VCs may also confer greater legitimacy to CV units, allowing them access to enhanced deal flow and skilled staff. Recent studies have confirmed that so-called "corporate venture capital" activities (i.e. external corporate venturing) can significantly improve the ability of parent companies to engage in exploratory learning and the recognition of technological opportunities (Maula, Keil, \& Zahra, 2002). While certain of these benefits would appeal to both internally- and externally-oriented CV units, enhanced access to syndicated deal flow and risk sharing are likely to be particularly relevant to externally focused units. Formally stated:

Hypothesis 4a: The higher the level of engagement in the VC community by the CV unit, the higher the performance of the unit.

Hypothesis 4b: The greater the importance of external business ideas to the CV unit, the greater the impact of engagement in the VC community on performance of the unit.

Hypothesis 5a: The more frequently a CV unit engages in deal syndication with external partners, the higher the performance of the unit.

Hypothesis 5 b: The greater the importance of external business ideas to the CV unit, the greater the impact of deal syndication on performance of the unit.

\section{Adoption of VC Model, Unit Performance and Survival}

It is established practice within evolutionary paradigms to investigate the survival rates of "species" of organizational forms. High survival rates of a particular form typically are interpreted to indicate the "fitness" of that form (and vice versa). In the private equity market, the LLP has progressively become the dominant organisation form over the last two decades (Fenn et al., 1995), thereby demonstrating its fitness in its landscape. In contrast, we know little about the factors influencing the longevity of CV units. Fast's (1978) research is an exception in finding that changed political will in the parent company frequently resulted in venture unit closure. One can therefore hypothesise that, if the VC form is relevant, CV firms adopting this model would have greater survival rates reflecting the superior performance ("fitness") of this form. Accordingly, it is proposed that:

Hypothesis 6: Venture unit performance mediates the relationship between the adoption of elements of the VC model by a CV unit, and unit survival.

\section{Methodology}

\section{Sample and Research Design}

The research consisted of three main phases. The first phase, mid-2001, comprised exploratory interviews with 50 individuals in 40 corporate venturing units across eight countries. These interviews were used to understand current practices regarding corporate venturing.

The second research phase (early- to mid-2002) involved surveying managers of CV units. The sampling frame comprised CV units listed in the Corporate Venturing Directory or in Venture Economics, along with additional venture units known to the researchers. These sources yielded 447 potential respondents to whom mail surveys were distributed. Follow-up calls found 120 of the venturing units to be inactive. Useable responses were received from 95 units: an eventual response rate of $29 \%$. Secondary data from Venture Economics-available for 71 CV units-was used to validate survey responses regarding the investment history of the units and to confirm the validity of performance proxies. ${ }^{1}$ 
ANOVAs and cross-tabs did not find any significant response biases by age of unit, monetary budget, average annual number of investments, number of employees or unit preference for 17 types of funding (e.g. start-up funding, first-stage funding, etc.). ${ }^{2}$ Significant differences were only found for the headquarter location of CV units $\left(\chi^{2}=39.563, p=.000\right)$ and their relative preference for seed funding $\left(\chi^{2}=6.695, \mathrm{p}=.010\right)$. Overall, these analyses suggested that respondents were largely representative of units in the sampling frame.

The third phase (May-July 2003), 18 months after the mail survey, entailed a telephonic survey to managers from the participating CV units. Respondents were asked whether or not their CV unit was still active.3 If appropriate, respondents were asked to recall the month and year in which it had ceased operations. We were able to speak with a person from 81 of the original $95 \mathrm{CV}$ units (85\% of the sample). Eighteen units (23\%) were found to have closed down subsequent to the survey, while the remaining $63(77 \%)$ were still active in one form or another. Web data was used to confirm the status of the remaining units.

\section{Dependent Variables}

The majority of the measures (dependent, independent and control measures) are derived from the mail survey. As no other studies (to the best of our knowledge) have examined the replication of VC structures and practices in CV contexts, the measures were developed by the researchers, drawing on prior literature where possible, as well as constructs emerging from the exploratory interviews. All multi-item scales were found (via orthogonal rotated factor analyses) to be uni-dimensional, and to demonstrate moderate to excellent internal consistency. Multi-item constructs (including Cronbach alphas) are detailed in Table 1.

As venture units are typically reluctant to provide "hard" data on the performance of their investments, and quantifying the strategic performance of ventures in large companies can present extreme challenges, CV managers' were asked for subjective perceptions of the performance of their units over the previous 3 years. The longitudinal data on CV unit survival supplemented these self-reported, cross-sectional measures.

Strategic value examined the perceived strategic value delivered by the unit including the creation of "options" on new technologies (Chesbrough, 2000, 2002; Maula et al., 2002), and wider awareness of the company's CV activities internally and externally.

Financial performance measured perceptions of how well the unit had delivered on three key financial objectives identified within the exploratory interviews.

Survival status recorded whether CV representatives classified their units as "active" or "inactive" in the telephone survey.

\section{Independent Variables}

Autonomy assessed the extent to which CV managers (compared to parent company executives) were responsible for making 10 types of investment decisions. Higher scores indicate the greater investment autonomy of CV unit managers.

Business unit decision involvement examined how extensively other business units within the parent company were involved in CV unit decision-making.

Carried interest asked CV managers how frequently carried interest was employed to incentivize venture unit staff (to examine the replication of the high-powered VC incentives).

Financial emphasis sought to differentiate those units that focus little from those that focus primarily on financial objectives.

$V C$ communication assessed the extent to which a CV unit maintained links with the VC sector, measured by frequency of communication.

Deal syndication examined whether a CV unit regularly engaged in deal syndication with VC firms.

\section{Control Variables}

Age of unit (in years) acted as a proxy for the impact of learning and experience effects on venture unit performance. Additionally, age was controlled to isolate history effects whereby more recently established units may be more likely to adopt elements of the VC model.

Region comprised a dummy variable to distinguish between US and non US-based venture units.

Number of investments controlled for possible "economies of scale" effects on performance. It may also tap a "learning curve" effect on performance. 
Internal orientation controlled for the relative emphasis placed by a unit on internally-generated investments in case this factor exerted a main effect on venture unit performance.

\section{Data Analysis}

Ordinary least squares regression and logistic regression were used to test the hypotheses. To reduce the potential impact of multicollinearity, all non-categorical independent and control variables were centred. VIF indices for the regression analyses were all below 3.00 (recommended threshold for variance inflation), indicating that multicollinearity was not of significant concern in the analyses. Furthermore, residual plots indicated that the use of OLS regression was appropriate given the error distributions of the predictor variables.

The threat posed by common method variance within the mail survey was investigated by subjecting the data to a Harman one-factor test. This test indicated that common method bias did not pose a significant threat to the survey data-a conclusion also borne out by the somewhat different pattern of findings of regression models for the strategic and financial performance measures.

\section{Results}

The first set of hypotheses ( $\mathrm{H}_{1}$ to $\left.\mathrm{H}_{5}\right)$ specifies direct and moderated relationships between the adoption of VC structures and practices, and venture unit performance. Tables 2 and 3 present the results of the OLS regression of strategic value on the independent and control variables and financial performance regressed on the same variables, respectively.

Hypothesis 1 posited a positive relationship between autonomy and venture unit performance. This hypothesis receives strong support in the financial performance model $(\beta=.385, \mathrm{p}=.030$ in the full model), but the relationship between the variables does not attain significance in the strategic value model. 4 Hypothesis 1 is thus partially supported. Hypothesis 2 posited a negative relationship between business unit involvement in the decisions of the venture unit and unit performance. As predicted, business unit involvement in decision-making was significantly, and negatively, associated with strategic performance $(\beta=-.104, p=.007$ in the full model $)$. Business unit involvement was not, however, found to be significantly associated with financial performance. Therefore, hypothesis 2 is partially supported.

Hypothesis 3 posited a moderated relationship between the use of carried interest compensation, the emphasis of the venture unit on financial goals, and venture unit performance: venture unit performance would be enhanced where a unit with strong financial goals adopted a carried interest compensation system. Neither the strategic value model nor the financial performance model found support for this proposition, which is consequently rejected.5

Hypotheses 4 and 5 posited direct and moderated relationships between, respectively, communication with VCs and deal syndication, and venture unit performance. Specifically, hypothesis 4 a stated that extensive communication with VCs would be associated with enhanced venture unit performance. Hypothesis $4 \mathrm{~b}$ posited that this association would be particularly strong where a VC unit focused primarily on internal ventures. Strong support was found for Hypothesis 4: communication with VCs was positively associated with strategic value $(\beta=.232, \mathrm{p}=.001$ in model 5$)$ and with financial performance $(\beta=.203, p=.042$ in model 5$)$. Partial support was received for hypothesis $4 \mathrm{~b}$ : the interaction term between VC communication and internal orientation was significant in the financial performance model $(\beta=-.160, p=$ .096 in the full model), but not in the strategic value model. Hypotheses 5 a found support in the strategic value model ( $\beta$ $=.182, \mathrm{p}=.017$ in model 6 ), but not the financial performance model. Hypothesis $5 \mathrm{~b}$ was not supported for either unit outcome.

Following Baron and Kenny (1986), a series of regression analyses were performed to test for mediation (by VC unit performance) between adoption of the VC model and venture unit survival (posited in Hypothesis 6). Using a combined measure where strategic and financial performance scales are equally weighted, overall unit performance partially mediated between adoption of the efficacious elements of the $\mathrm{VC}$ model and unit survival. This is the case for unit strategic performance too, but not the model where only financial performance is measured (tables available from authors). Accordingly, Hypothesis 6 finds moderate support overall.

\section{Discussion and Implications}

As noted, this present research is one of the most extensive, contemporary empirical studies undertaken in the field of corporate venturing. The use of a multiple stage enquiry and the involvement of nearly $100 \mathrm{CV}$ organisations across 3 continents to retrieve data both in direct discussion and via postal questionnaire distinguish the scale of this enquiry. The findings of the research challenge simplistic interpretations. While there are a number of elements of the dominant venture capital firm/LLP model which have clear relevance for corporate investors, our findings indicate that recommendations need to be strongly qualified and placed in a clearly specified context.

Only two elements of the VC model were found to have consistent effects across both the strategic value and financial performance models. Carried interest was demonstrated to be uniformly ineffective for both strategic and financially-oriented CV units. Also, increased contact with VC firms appears to be desirable across all types of CV unit, albeit to a lesser extent within the financial model. Generally, prescriptions cannot be made without reference to the objectives of the CV unit itself. Particularly, the objective of the corporate venture unit's investment activity strongly 
differentiates between structures and practices which may, or may not, be effective. For example, business unit involvement in decision making has significant, negative implications when the CV unit seeks to contribute to strategic value. Essentially, if a firm wishes its corporate venturing arm to add value to overall strategic effectiveness, it is incumbent on the head office to ensure that the actions of the CV unit are not confounded by an interfering business unit. Yet, if the goal of the corporation is to use the CV unit for a primarily financial contribution, the involvement of the business unit ceases to be significant. Additionally, the research supports the assertions that CV units need autonomy from the parent organisation. However, this finding is qualified as autonomy does not serve to improve the strategic value model, merely the financial performance model.

Determining the core purpose of the CV unit and quantifying the relative importance of financial or strategic goals is an endemic problem for researchers. Yet, it is difficult to give these two alternative modus operandi equal status. The likelihood of most CV units being of a scale that can directly influence the financial results of the parent organisation is small. Given the portfolio of core activities of the parent organisation, the financial contribution of the CV unit is likely to remain modest. However, the potential for strategic value is potentially far greater. Indeed, our analysis of the mediating role venture unit performance plays between adoption of elements of the VC model and venture unit survival, indicates that strategic logic is a more important mediator (than financial performance) on both CV unit performance and survival. Put another way, strategic performance is more salient than financial performance in the parent's decision to either support or to terminate a CV activity. In its strategic role, the CV unit provides market intelligence and environmental scanning in order to identify new product/market opportunities (and threats). The persistence of strategic CV activity amongst technology-based firms may indeed be explained by its efficacy in the early identification and exploitation of novel and disruptive technologies-an outcome that is likely to have widespread value to the parent.

Inevitably our research poses as many questions as answers. For example, we can say little as to the underlying mechanisms through which engagement with VC firms benefits CV units, or why autonomy plays such a critical role to venture unit financial performance. We too have little to say yet on how CV units can practicably balance strategic and financial objectives. Difficulties of access to information and the consequent ambiguities of available metrics also continue to make CV research extremely challenging. Nonetheless, we can start to advise corporations on the value of specific components of the dominant VC model. Ironically, we can confirm the spirit of what CV units and corporate head offices already know. Successful corporate venturing, regardless of objectives, is a uniquely challenging managerial activity.

CONTACT: Susan Hill, London Business School, Sussex Place, Regent's Park, London, NW1 4SA, United Kingdom; (T) +44 7812016451 ; (F) +44 20 7724 7875; shill@london.edu

\section{Notes}

1. Venture Economics investment data has been used extensively to proxy private equity returns (Gompers \& Lerner, 1998; Maula \& Murray, 2001). The self-reported portfolio data was highly consistent with Venture Economics data ( $\mathrm{p}=$ .000).

2. The tests for non-response bias found that the proportion of European respondents was somewhat higher than expected, whilst fewer than expected responses were received from North American CV units; the proportion of respondents who expressed a preference for seed funding was higher than that amongst non-respondents.

3. The process followed to establish the survival status of venture units allowed for a degree of respondent discretion, both in deciding whether the unit was still "operating" and in recalling, where applicable, the month and year of closure. Overall, we judged the importance of obtaining a high response rate through brief telephone interviews to outweigh the risk of obtaining data with a degree of imprecision. As a precaution, the interviewer recorded any mixed perceptions of the unit status as fully as possible, and the researchers jointly classified such units.

4. As prominent scholars have conflicting views over the role of autonomy in venture unit performance, models using a squared term for autonomy were also run to investigate the possibility of a curvilinear relationship. In no instances did the squared term achieve significance.

5. A number of variants on the carried interest measure were also tested. For example, one alternative tested was CV usage of either carried interest systems, equity-based systems, or "direct financial incentives"; another used the incidence of flat-rate salaries (reverse-scored). Findings were consistent with those reported here.

\section{References}

Baron, R.M., \& D.A. Kenny. (1986) "The Moderator-Mediator Variable Distinction in Social Psychological Research: Conceptual, Strategic, and Statistical Considerations.” Journal of Personality and Social Psychology, 51(6): $1173-1182$.

Barry, C.B. (1994) “New Directions in Research on Venture Capital.” Financial Management, 23(3): 3-15.

Birkinshaw, J. (1997) "Entrepreneurship in Multinational Corporations: The Characteristics of Subsidiary Initiatives." Strategic Management Journal, 18(3): 207-209.

Birkinshaw, J., R. van Basten Batenburg, \& G. Murray. (2002) Corporate Venturing: The State of the Art and the Prospects for the Future. London Business School: Centre for the Network Economy. 
Block, Z., \& I.C. MacMillan. (1993) Corporate Venturing. Boston, MA: Harvard Business School Press.

Block, Z., \& O. Ornati (1987) “Compensating Corporate Venture Managers.” Journal of Business Venturing, 2: 41-51.

Brody, P., \& D. Ehrlich. (1998) “Can Big Companies become Successful Venture Capitalists?” McKinsey Quarterly, 2: $50-63$.

Burgel, O. (2000) UK Venture Capital and Private Equity as an Asset Class for Institutional Investors. London: British Venture Capital Association/ London Business School.

Burgelman, R.A. (1984) "Designs for Corporate Entrepreneurship in Established Firms." California Management Review, 26(3): 154-166.

Chesbrough, H.W. (2000) "Designing Corporate Ventures in the Shadow of Private Venture Capital." California Management Review, 42(3): 31-49.

Chesbrough, H.W. (2002) “Making Sense of Corporate Venture Capital.” Harvard Business Review, March: 4-11.

Coveney, P.F., J.J. Elton, B.R. Shah, \& B.W. Whitehead. (2002) "Rebuilding Business Building.” McKinsey Quarterly, Special Edition (2): 38-47.

Donahoe, J., P. Schefter, \& D. Harding. (2001) Corporate Venturing: Management Fad or Lasting Trend? Bain \& Company Inc. Research Paper.

Drucker, P.F. (1985) Innovation and Entrepreneurship: Practice and Principles. New York: Harper and Row.

Fast, N. (1978) The Rise and Fall of Corporate New Venture Divisions. Ann Arbor, MI: UMI Research Press.

Fenn, G.W., N. Liang, \& S. Prowse. (1995) The Economics of the Private Equity Market. Washington, DC: Board of Governors of the Federal Reserve System.

Galbraith, J. (1982) “Designing the Innovative Organization.” Organizational Dynamics, Winter: 5-25.

Gompers, P.A., \& J. Lerner. (1998) The Determinants of Corporate Venture Capital Success: Organizational Structure, Incentives, and Complementarities. National Bureau of Economic Research: Working Paper 6725.

Gompers, P.A., \& J. Lerner. (1999) The Venture Capital Cycle. MIT Press: Cambridge, MA.

Hellman, T. (2000) "Venture capitalists: The coaches of Silicon Valley.” In W. Miller, C. M. Lee, M. Gong Hanock, \& H. Rowen (Eds.), Silicon Valley Edge: A Habitat for Innovation and Entrepreneurship. Stanford University Press: Stanford, CA.

Lerner, J. (1994) “The Syndication of Venture Capital Investments.” Financial Management, 23(3): 16-27.

Maula, M., \& G. Murray. (2001) "Corporate Venture Capital and the Creation of US Public Companies: The Impact of Sources of Venture Capital on the Performance of Portfolio Companies.” In M. A. Hitt, R. Amit, C. Lucier, \& B. Shelton (Eds.), Strategy in the Entrepreneurial Millennium. New York: John Wiley \& Sons.

Maula, M., E. Autio, \& G. Murray. (2003) "Corporate Venture Capitalists and Independent Venture Capitalists: What do They Know, Who do They Know, and Should Entrepreneurs Care?” Small Business Economics.

Maula, M., T. Keil, \& S.A. Zahra. (2003) “Corporate Venture Capital and Recognition of Technological Discontinuities.” Paper presented at the Academy of Management Annual Meeting, Seattle, WA, August 1-6.

Rind, K. (1981) “The Role of Venture Capital in Corporate Development.” Strategic Management Journal, 2: 169-180.

Rumelt, R.P. (1987) “Theory, Strategy and Entrepreneurship”. In D. J. Teece (Ed.), The Competitive Challenge: Strategies for Industrial Innovation and Renewal: 137-158. California: Centre for Research in Management.

Sahlman, W.A. (1990) “The Structure and Governance of Venture-Capital Organizations.” Journal of Financial Economics, 27: 473-521.

Siegel, R., E. Siegel, \& I.C. MacMillan. (1988) “Corporate Venture Capitalists: Autonomy, Obstacles, and Performance.” Journal of Business Venturing, 3: 233-247.

Sohl, J.E. (2002) “The Private Equity Market’s Gyrations: What has been Learned?” Venture Capital, 4(4): $267-274$.

Sykes, H.B. (1990) “Corporate Venture Capital: Strategies for Success.” Journal of Business Venturing, 5: 37-47.

Wright, M., \& A. Lockett. (2003) "The Structure and Management of Alliances: Syndication in the Venture Capital Industry.” Journal of Management Studies, 40(8): 2073-2104.

Zider, B. (1998) “How Venture Capital Works.” Harvard Business Review, November-December: 131-139. 
rigure 1

Theoretical Model

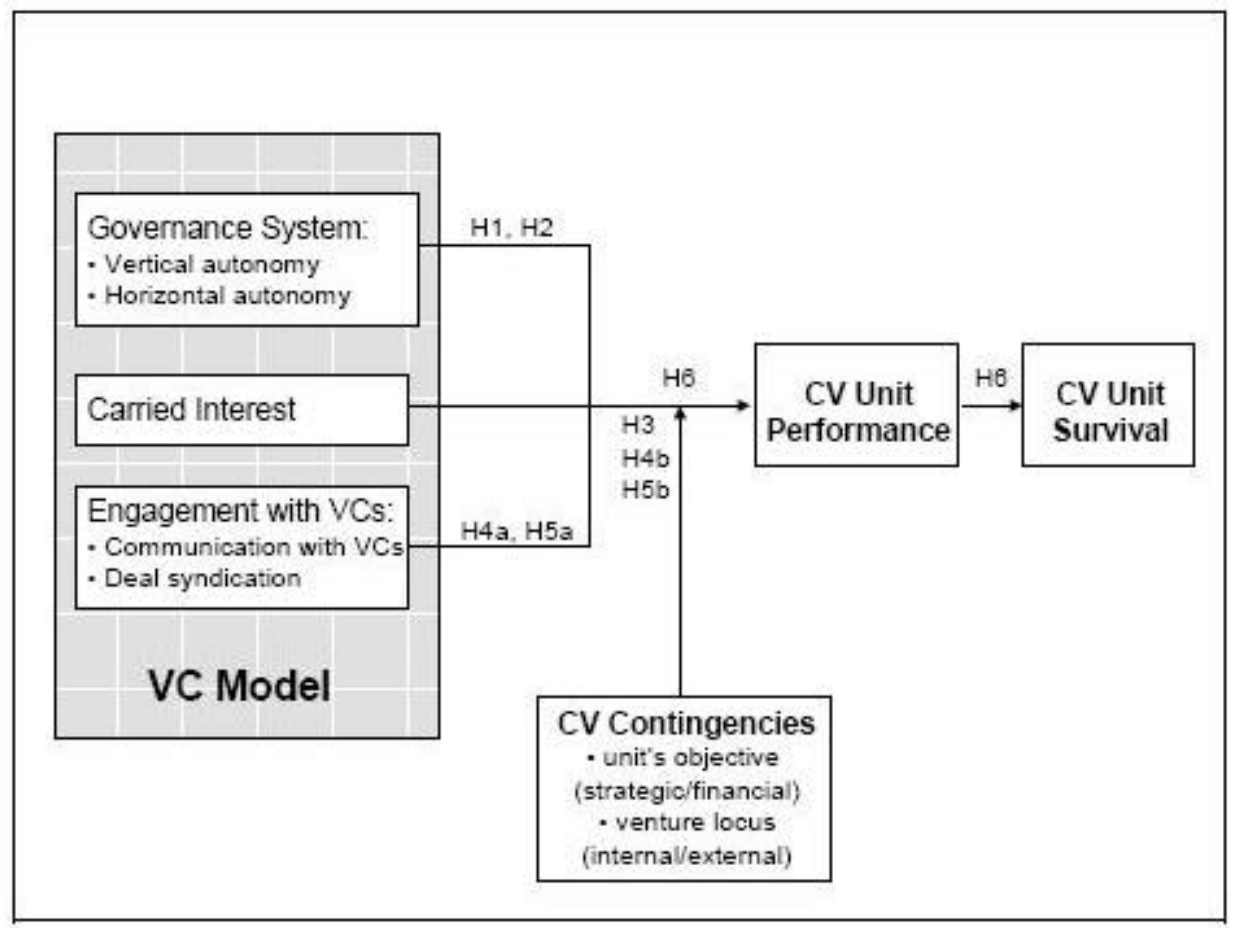

Table 1

Multi-Item Measures

\begin{tabular}{|c|c|c|c|}
\hline Construet & Items & Response Format & $\alpha$ \\
\hline Strategic Value & $\begin{array}{l}\text { How well does the unit deliver on this objective? } \\
\text { 1. Creation of new companies that increase demand for our } \\
\text { products or technology } \\
\text { 2. Window on emerging technologies } \\
\text { 3. Increased visibility/ awareness of corporation } \\
\text { 4. Creation of options on emerging tecluologies } \\
\text { 5. Increased recognition in rest of corporation of the } \\
\text { importance of new business development } \\
\text { 6. Creation of spinout companies } \\
\text { 7. Search for next core business for the corporation }\end{array}$ & $\begin{array}{l}5 \text {-point Likert scale, where } 1= \\
\text { below expectation, } 3=\text { equal to } \\
\text { expectation, and } 5=\text { above } \\
\text { expectation }\end{array}$ & .80 \\
\hline $\begin{array}{l}\text { Financial } \\
\text { performance }\end{array}$ & $\begin{array}{l}\text { How well does the unit deliver on this objective? } \\
\text { 1. Financial retun to the comporation (e.g. IRR) } \\
\text { 2. Coumbution to top-line growth } \\
\text { 3. Increased valuation of corporate stock }\end{array}$ & $\begin{array}{l}\text { 5-point Likert scale, where } 1= \\
\text { below expectation, } 3=\text { equal to } \\
\text { expectation, and } 5=\text { above } \\
\text { expectation }\end{array}$ & .72 \\
\hline Autonomy & 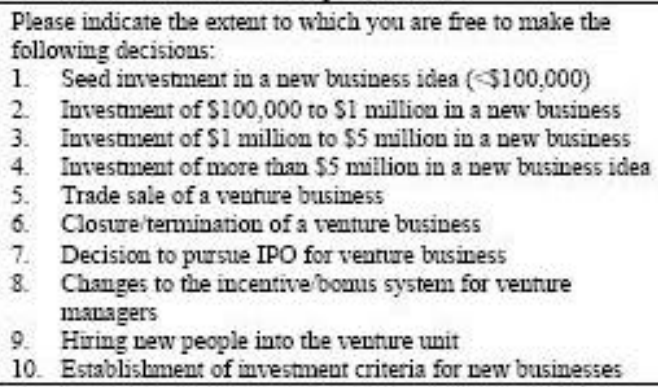 & $\begin{array}{l}\text { Respouse options: decision made } \\
\text { exclusively by venture vuit } \\
\text { managers; decision made with } \\
\text { ratification by or consultation } \\
\text { with corporate board/execurives; } \\
\text { or decision made primarily by } \\
\text { corporate board/executives }\end{array}$ & .88 \\
\hline $\begin{array}{l}\text { Busines5 unit } \\
\text { decision } \\
\text { involvement }\end{array}$ & $\begin{array}{l}\text { If a potential busivess venture is in the domain of an existing } \\
\text { busivess uwit, to what extent do you do the following: } \\
\text { 1. Seek their cooperation in working with us on the business } \\
\text { venture } \\
\text { 2. Require their approval/ sign-off before we make an } \\
\text { investment } \\
\text { 3. Try to encourage them to retain ownership of the venture, } \\
\text { even if we provide funding }\end{array}$ & $\begin{array}{l}7 \text {-point Likert scale, where } 1= \\
\text { not at all and } 7=\text { to a great } \\
\text { extent. A "not applicable" } \\
\text { response option was also } \\
\text { provided. }\end{array}$ & .69 \\
\hline $\begin{array}{l}\text { Financial } \\
\text { emphasis }\end{array}$ & $\begin{array}{l}\text { 1. How important is the objective of financial return to the } \\
\text { corporation? } \\
\text { 2. Do you measure the internal rate of renun (IRR) of your } \\
\text { unit? } \\
\text { 3. Do you measure the financial gain of portfolio } \\
\text { companies? }\end{array}$ & $\begin{array}{l}\text { Item } 1 \text { : response scale of } 1 \text { to } 3 \text {, } \\
\text { where } 1=\text { not at all, } 2=\text { minor } \\
\text { inportance, and } 3=\text { major } \\
\text { inmportance } \\
\text { Items } 2 \text { and } 3: 7 \text {-point Likert } \\
\text { scale, where } 1 \text { = not at all, and } 7 \\
=\text { to a great extent }\end{array}$ & .75 \\
\hline $\begin{array}{l}\text { VC } \\
\text { communication }\end{array}$ & $\begin{array}{l}\text { Indicate the frequency with which you, or your team, } \\
\text { communicate with the following individuals or units: } \\
\text { 1. Partmer VC companies } \\
\text { 2. Other companies or individuals in the VC community }\end{array}$ & $\begin{array}{l}\text { Response options: } 1 \text { (daily); } 2 \\
\text { (weekly), } 3 \text { (monthly), } 4 \text { (rarely), } \\
5 \text { (never), or "not applicable" }\end{array}$ & .82 \\
\hline
\end{tabular}




\begin{tabular}{|c|c|c|c|}
\hline $\begin{array}{l}\text { Deal } \\
\text { syudication }\end{array}$ & $\begin{array}{l}\text { For a typical investment (e.g. a portfolio company, an internal } \\
\text { new business project), please indicate: } \\
\text { 1. the percentage equity held by venture unit } \\
\text { 2. the number of other equity partners (including VCs and } \\
\text { other corporates) involved. }\end{array}$ & $\begin{array}{l}\text { Item } 1 \text { respouse optious: } 100 \% \text {; } \\
\text { majority stake; minority stake; } \\
\text { small stake ( } 15 \% \text { ). } \\
\text { Item } 2 \text { response options: nove; } \\
\text { one; two; more than two. }\end{array}$ & .79 \\
\hline $\begin{array}{l}\text { Internal } \\
\text { orientation }\end{array}$ & $\begin{array}{l}\text { Please indicate the extent to which you do the following: } \\
\text { 1. We invest in internally-generated busimess ideas to } \\
\text { promote organic growth } \\
\text { 2. We invest in internally-generated business ideas with a } \\
\text { view to spimning them out as separate businesses } \\
\text { 3. We invest in internally-generated business ideas to } \\
\text { leverage under-utilised corporate assets (e.g. IP) }\end{array}$ & $\begin{array}{l}\text { Respouse optious: } 1 \text { (never); } 2 \\
\text { (only in exceptional cases), } 3 \\
\text { (occasionally), } 4 \text { (frequently), } 5 \\
\text { (almost always), or "not } \\
\text { applicable" }\end{array}$ & .73 \\
\hline
\end{tabular}

Table 2

OLS Regression Analysis-Impact of VC Model on Strategic Value

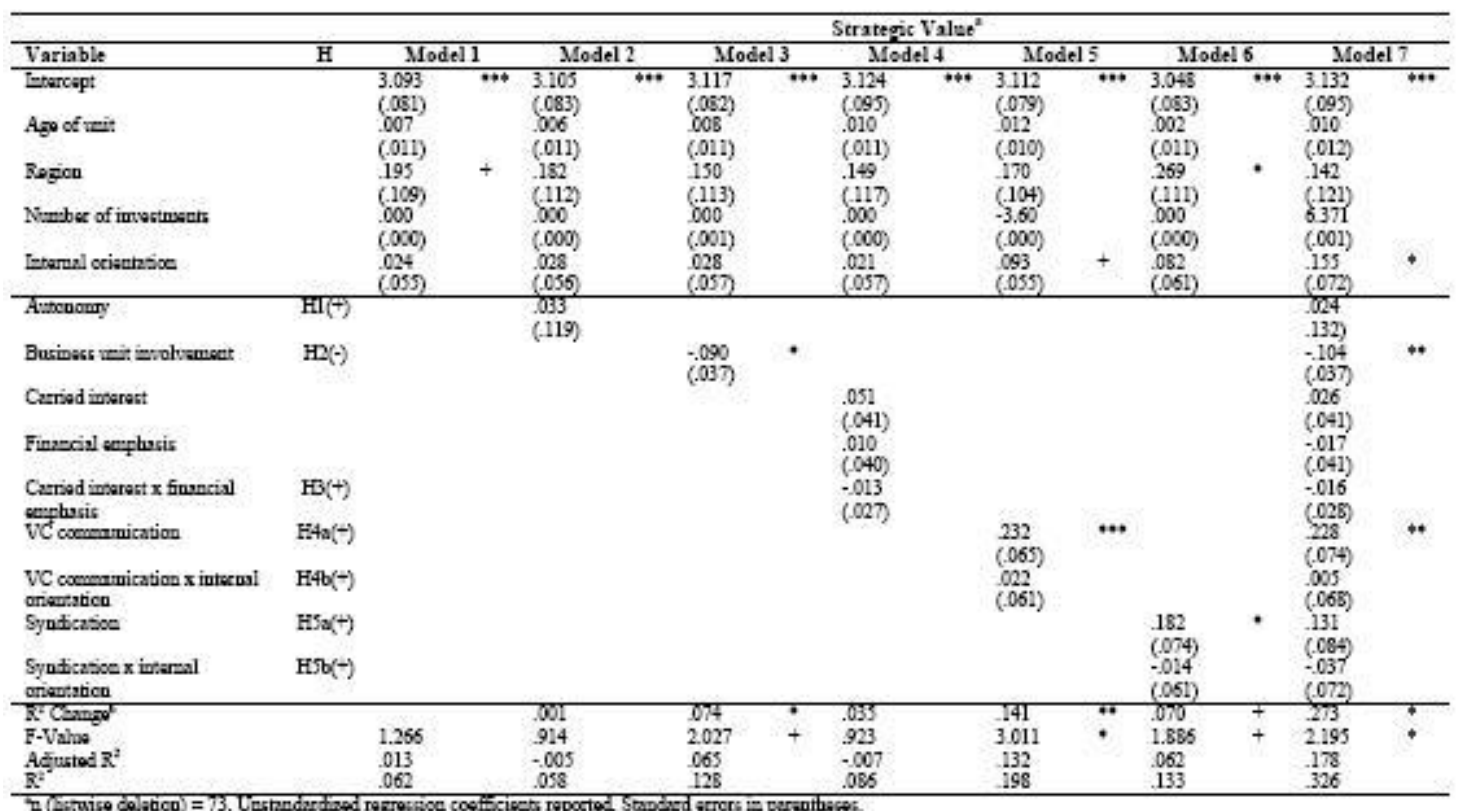

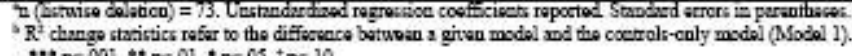

$\cdots p=001 * * p<01 * p<05{ }^{+} p<10$

Table 3

OLS Regrassion Analysis - Impact of VC Model on Financlal Pertormance

\begin{tabular}{|c|c|c|c|c|c|c|c|c|c|c|c|c|c|}
\hline \multirow{2}{*}{ Variable } & \multirow{3}{*}{ H } & \multicolumn{12}{|c|}{ Financial Performance } \\
\hline & & \multicolumn{2}{|c|}{ Model 1 } & \multicolumn{2}{|c|}{ Model 2 } & Model 3 & \multicolumn{2}{|c|}{ Model 4} & \multicolumn{2}{|c|}{ Model5 } & Model 6 & \multicolumn{2}{|c|}{ Model 7} \\
\hline Interoept & & 3.035 & $\omega$ & 3.054 & $\cdots$ & $3040 \quad 600$ & 2948 & $\omega$ & 2.989 & $\omega$ & $3.030 \quad 60$ & 2955 & $\cdots$ \\
\hline Age or unat. & & $019^{\prime}$ & & 017 & & .20 & .028 & - & .024 & + & .016 & 025 & + \\
\hline & & (.014) & & (014) & & (015) & (.013) & & $(014)$ & & (015) & (.015) & \\
\hline Begent & & $-\infty 0^{\circ}$ & & -037 & & -037 & -031 & & -.019 & & $\infty 0^{\circ}$ & -119 & \\
\hline & & $(.145)$ & & (.145) & & (159) & (143) & & $(145)$ & & (154) & (164) & \\
\hline Number of & & 001 & + & .001 & & $\infty 1$ & 601 & & .000 & & $\infty 1$ & 900 & \\
\hline investreets & & $(, 001)$ & & $(000)$ & & (001) & $(\infty 01)$ & & $(001)$ & & (001) & $(.001)$ & \\
\hline Intemal criethasion & & 094 & & 107 & & . ass & 023 & & 152 & + & .125 & 112 & \\
\hline Aunson:any & $\mathrm{Hl}(+)$ & & & $\frac{6739}{332}$ & \% & $(0,5)$ & $(090)$ & & & & (1085) & $\frac{(.101)}{385}$ & $\%$ \\
\hline & & & & $(.152)$ & & & & & & & & (.172) & \\
\hline BU indiveneat & $\mathrm{H} 2(-)$ & & & & & .003 & & & & & & $\cos$ & \\
\hline Carriad inferst & & & & & & & -018 & & & & & $\begin{array}{r}-017 \\
-0058\end{array}$ & \\
\hline Firoctivel enphisais & & & & & & & $\begin{array}{l}128 \\
(.056)\end{array}$ & - & & & & $\begin{array}{l}0.47 \\
(.055)\end{array}$ & \\
\hline Caniad invest $x$ & $\mathrm{H} 3(+)$ & & & & & & $\cos ^{2}$ & & & & & 019 & \\
\hline 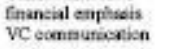 & $\mathrm{H} 2 \mathrm{w}_{(+)}+\mathrm{t}$ & & & & & & $(\cos 2)$ & & 303 & - & & $(.047)$ & \\
\hline & & & & & & & & & (008) & & & (113) & \\
\hline VC ecanautiorican $x$ & $\mathrm{HAb}(\mathrm{x}+)$ & & & & & & & & $\begin{array}{l}-104 \\
\cos 80\end{array}$ & & & $\begin{array}{c}160 \\
0009\end{array}$ & + \\
\hline 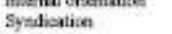 & HSSO(t) & & & & & & & & & & .060 & .033 & \\
\hline & & & & & & & & & & & $(100)$ & (1) & \\
\hline Syadiention $x$ & HSB $(+)$ & & & & & & & & & & 027 & -015 & \\
\hline indernl oremtatios & & & & & & & & & & & $(0,4)$ & $(.085)$ & \\
\hline $\mathrm{R}^{2}$ Counge" & & & & 062 & ? & कon & 100 & + & 063 & + & कos & .200 & \\
\hline F. Vwilace & & 2.089 & + & 2.06 & - & 1.455 & 2534 & - & 2.320 & - & 1.453 & 1.949 & - \\
\hline$A d j=$ sted $R^{2}$ & & 059 & & 110 & & cass & 140 & & 103 & & .038 & .164 & \\
\hline $\mathrm{K}^{1}$ & & 113 & & 175 & & 109 & 231 & & 181 & & 121 & 335 & \\
\hline
\end{tabular}

(C) 2005 Babson College. All rights reserved. Last updated September 2005. 
